\title{
Effect of tree species substitution on organic matter biodegradability and mineral nutrient availability in a temperate topsoil
}

\author{
Judicaël MoukoumI $^{\mathrm{a}, \mathrm{b} *}$, Colette MUNIER-LAMY ${ }^{\mathrm{a}}$, Jacques BeRTHELIN ${ }^{\mathrm{a}}$, Jacques RANGER ${ }^{\mathrm{b}}$ \\ a Laboratoire des Interactions Microorganismes Minéraux Matières Organiques dans les Sols (LIMOS), UMR 7137, CNRS-UHP Nancy I, \\ Faculté des Sciences, BP 239, 54506 Vandœuvre-lès-Nancy Cedex, France \\ ${ }^{\mathrm{b}}$ Laboratoire de Biogéochimie des Écosystèmes Forestiers (BEF-INRA), Centre de Recherche Forestière, 54280 Champenoux, France
}

(Received 4 July 2005; accepted 27 January 2006)

\begin{abstract}
In the Breuil-Chenue experimental site (Morvan, France), the native forest, a 150-year-old coppice with standards dominated by beech was partly clear-cut thirty years ago and replanted with several tree species. Soil samples were collected from the $\mathrm{A}_{1}$ horizon, in the $0-5 \mathrm{~cm}$ layer of the preserved native forest and three plantations: European beech, Douglas-fir and Norway spruce. Aliquots of 0-2 mm sieved soils were incubated for 40 days under laboratory conditions $\left(15^{\circ} \mathrm{C}\right.$, water-holding capacity). Carbon-mineralization was monitored; mineral nitrogen, water-extractable organic carbon and mineral elements were determined before and after the incubation. The release of $\mathrm{CO}_{2}$ decreased in the order: spruce $>$ native forest $>$ beech > Douglas-fir, whereas nitrogen net mineralization decreased in the opposite order. Douglas-fir and beech soils were characterised by high nitrification activity and high solubilization of $\mathrm{Ca}, \mathrm{Mg}$, and $\mathrm{Mn}$. Native forest and spruce soils were characterized by low nitrification activity, high carbon-mineralization and high solubilization of $\mathrm{Fe}$ and $\mathrm{Al}$.
\end{abstract}

forest tree species substitution / topsoil organic matter / biodegradability / nutrient availability / carbon and nitrogen mineralization

Résumé - Effet de la substitution des essences forestières sur la biodégradabilité des matières organiques et la disponibilité des éléments majeurs dans les horizons superficiels d'un sol tempéré. Il y a 30 ans, dans le site atelier de Breuil-Chenue (Morvan, France), la forêt native, un taillis sous futaie de 150 ans à dominante de hêtre, était partiellement coupée à blanc, puis replantée avec diverses essences. Des échantillons de sol ont été prélevés dans l'horizon A1 $(0-5 \mathrm{~cm})$ sous la forêt native préservée et les plantations de hêtre, Douglas et épicéa. Les fractions de sols ( $2 \mathrm{~mm})$ ont été incubées au laboratoire $\left(15^{\circ} \mathrm{C}\right.$, capacité au champ). La minéralisation du carbone a été suivie périodiquement. L'azote minéral, le carbone et les éléments hydrosolubles ont été quantifiés avant et après incubation. La minéralisation du carbone décroît dans l'ordre : épicéa $>$ forêt native $>$ hêtre $>$ Douglas, alors que celle de l'azote décroît dans l'ordre inverse. Les sols de Douglas et de hêtre se caractérisent par une forte nitrification et solubilisent plus $\mathrm{Ca}, \mathrm{Mg}$ et $\mathrm{Mn}$. Ceux de la forêt native et d'épicéa nitrifient peu, minéralisent fortement le carbone et solubilisent plus Fe et Al.

substitution d'essences forestières / horizon organique superficiel / biodégradabilité / disponibilité des éléments / minéralisation du carbone et de l'azote

\section{INTRODUCTION}

Forest tree species affect soil functions in various ways and at various rates, and particularly by the changes in carbon and nitrogen cycles. In forest soils, humification and weathering processes depend on vegetation, parent rock material, climate and topography which control the biophysico-chemical processes [5, 14, 33, 45]. Vegetation is one of the major parameter at the origin of the differentiation in the humification and weathering processes. It is relatively well known that some forest floors decay more rapidly, as for deciduous species like European ash, Elm and Basswood, and produce a mulltype humus, whereas others, as different coniferous species, decay more slowly and produce mor or moder-type humus $[7,14,21,38]$. Norway spruce for example is known to acidify the soil by providing and accumulating strong acidic organic matter [35].This well admitted divergence between ameliorating and degrading species has to be carefully considered in relation with soil parent material characteristics, and environmental conditions $[14,32]$ The introduction of forest tree species such as fast growing species (spruce, Douglas...) as it was managed much more in the half past century can therefore affect biological and biogeochemical soil functions $[1,7,8,30]$. In fact, forest tree species substitution modifies the annual input of organic matter, both qualitatively and quantitatively, and the rate and issue of its decomposition [6,7,21,27]. As a consequence, biological activity, biodegradation-mineralization processes, release, mobility and cycling of nutrients $(\mathrm{N}, \mathrm{P}, \mathrm{Ca}$, $\mathrm{Mg}, \mathrm{Fe} . .).[5,15,46]$ can be affected or significantly modified. Several studies carried out under laboratory conditions have improved the knowledge of biodegradation and mineralization processes of soil organic compounds [12,17] and on some aspects of mineral weathering $[4,5]$. However, the effect of forest tree species substitution on the key-processes of organic matter biodegradation and nutrient availability is not well known.

\footnotetext{
*Corresponding author: judicael.moukoumi@limos.uhp-nancy.fr
} 
In order to determine and verify if under similar climatic and soil conditions, litter material from different tree species would decompose at different rates resulting in different kinetics of carbon and nitrogen mineralization and nutrient release, laboratory experiments have been done.

Soil samples from adjacent plots of different tree species growing on the same original soil and same climatic conditions, were incubated in laboratory devices, to investigate the effect of forest tree species substitution on (i) the biodegradability and mineralization of carbon and nitrogen of the soil organic matter, and (ii) consequently on the mobility and availability of major mineral nutrients.

\section{MATERIALS AND METHODS}

\subsection{Study site}

The study site was located in the state forest of Breuil-Chenue, Morvan Regional Natural Park (Nièvre, France), north eastern part of Massif Central. The elevation is around $650 \mathrm{~m}$ and the mean annual rainfall and temperature are $1280 \mathrm{~mm}$ and $9{ }^{\circ} \mathrm{C}$ respectively. The parent rock material is a coarse grained leucogranite with two micas relatively poor in iron, magnesium and calcium and designated as granite de la Pierre-qui-Vire [39]. The granite saprolite was cryoturbated and covered by a centimetric to decimetric layer of eolian loam [2]. Soils are acidic $(4<\mathrm{pH}<4.5)$ with a poorly saturated cation exchange capacity (CEC). Humus-type varies from acid mull in the young forest plantations to typical moder in the native forest. The native forest is a coppice with standards dominated by 150 -year-old beech trees, which was intensively exploited up to the beginning of the 20th century for fuel-wood. Thirty years ago, part of this forest was clearcut and afforested in plots of 0.1 ha with various tree species (Oak Quercus petraea, European beech Fagus sylvatica L., Norway spruce Picea abies Karst., Douglas fir Pseudotsuga menziesii Mirb. Franco, Pine Pinus nigra Arn., and Nordmann fir Abies nordmanniana Spach) [10], whereas the other part of the native forest was preserved as a reference. When the plantations were established in 1976, the soil of the Breuil-Chenue forest was homogeneous and identical for all plots $[10,34]$. The initial objective of this experiment was to study the potential improvement of wood production by alien species and to evaluate the impact of different tree species on soil fertility. More information on the experimental site is available in Bonneau et al. [10], Ranger et al. [34] and Simonsson et al. [40].

\subsection{Soil sampling}

Soil samples were collected with a stainless steel cylinder system (8 cm inner diameter) on January 29th 2002 from the $0-5 \mathrm{~cm} \mathrm{~A}_{1}$ organo-mineral layer, in four plots, i.e., the native forest and three plantations (beech, spruce and Douglas-fir). Six various sampling points were selected randomly in each plot. The six samples were pooled in the field (to form a composite sample for each plot), then sieved $(<2 \mathrm{~mm})$ in the laboratory and stored in the dark at $4{ }^{\circ} \mathrm{C}$ until their use.

\subsection{Laboratory incubation design}

Ten grams of soil were introduced in serum bottles $(250 \mathrm{~mL})$ hermetically sealed, and incubated for 40 days at $15{ }^{\circ} \mathrm{C}$ in the dark.
Twenty-five replicates were performed for each type of soil corresponding to the four tree species. For incubation, soil moisture was at water-holding capacity (WHC). No aeration to remove the $\mathrm{CO}_{2}$ from the bottle atmosphere was undertaken during the incubation. The available oxygen initially present in the bottle was sufficient to maintain oxic atmospheric conditions

\subsection{Analysis}

$\mathrm{C}$-mineralization was evaluated as $\mathrm{CO}_{2}-\mathrm{C}$ release in the bottle atmosphere. For all the 25 replicates per soil, periodically, every 2 then 3 days at the beginning of incubation, and every 5 days over the 20th day, $4 \mathrm{~mL}$ of gas were sampled in the flask headspace with a syringe and injected immediately into the $\mathrm{CO}_{2}$ analyser (BINOS 1004 Infrared Gas analyser).

Water-soluble elements were extracted from the soil before and after incubation, with deionised water using a 1:10 (w/v) ratio. After mechanical shaking $(60 \mathrm{~min})$ and centrifugation $(20 \mathrm{~min}$ at $3500 \mathrm{rpm}$ ), water extracts were filtered using $0.45 \mu \mathrm{m}$ Whatman filters. In the filtered solutions, nitrate $\left(\mathrm{NO}_{3}^{-} \mathrm{N}\right)$ and water extractable organic carbon (WEOC) were analysed by ionic chromatography (chromatograph Dionex series 4500i) and with an Auto analyser Dohrman DC 190 respectively. $\mathrm{Ca}, \mathrm{Mg}, \mathrm{Mn}, \mathrm{Fe}$ and $\mathrm{Al}$ were determined by inductive plasma emission spectroscopy (ICP-AES), (Jobin Yvon JY 32). Ammonium $\left(\mathrm{NH}_{4}-\mathrm{N}\right)$ was extracted with a $(0.02 \mathrm{~N}) \mathrm{KCl}$ solution at $1: 10(\mathrm{w} / \mathrm{v})$ ratio and quantified with the ammonium Spectroquant method (Merck product code 1.1475.0001).

Both total carbon $\left(\mathrm{C}_{t}\right)$ and total nitrogen $\left(\mathrm{N}_{t}\right)$ were determined in solid samples by combustion at $1020{ }^{\circ} \mathrm{C}$ in a CHNS-O 1108 Carlo Erba analyser. Effective Cation Exchange Capacity (CEC) was measured at soil $\mathrm{pH}$, according to Rouiller et al. [37], using a buffered $0.5 \mathrm{~N} \mathrm{NH}_{4} \mathrm{Cl}$ salt solution. The exchangeable collected cations $(\mathrm{Ca}$, $\mathrm{Mg}, \mathrm{Na}, \mathrm{K}, \mathrm{Fe}, \mathrm{Al}, \mathrm{Mn}$ ) were analysed by ICP. $\mathrm{pH}_{H 2 O}$ was measured in 1:2.5 (w/v) soil/water ratio suspension.

\subsection{Statistical analysis}

Spatial plot variability was taken into account on the initial sampling (6 replicates). Then the sample pooling was made to provide an average plot sample to be used in the laboratory incubation experiment where 25 replicates were done for each plot. So the plot variability was minimized that can be considered as pseudo-replication [18]. The differences between tree species were determined on subsamples, before and after incubation, by ANOVA with the NewmanKeuls test. Principal component analysis (PCA) was performed with Log-transformed variables. The statistical software StatBox version 2.5 was used.

\section{RESULTS}

\subsection{Soil analytical characteristics}

The $A_{1}$ layer texture was similar for all different plots as shown in Table I. It was sandy-silty and dominated by coarse sand. The clay content varied from $16.4 \%$ to $20.6 \%$ in the spruce and beech soils respectively. Soils under native forest 
Table I. Characteristics of the $<2 \mathrm{~mm}$ fraction of the $\mathrm{A}_{1}$ organo-mineral topsoil $(0-5 \mathrm{~cm})$.

\begin{tabular}{|c|c|c|c|c|c|c|c|c|c|c|}
\hline \multirow[t]{2}{*}{$\overline{\text { Plots }}$} & Clay & Fine silt & Coarse silt & Fine sand & Coarse sand & \multirow{2}{*}{$\begin{array}{c}\mathrm{C}_{t} \\
(\%)\end{array}$} & \multirow{2}{*}{$\begin{array}{c}\mathrm{N}_{t} \\
(\%)\end{array}$} & \multirow[t]{2}{*}{$\mathrm{C} / \mathrm{N}$} & \multirow{2}{*}{ 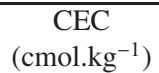 } & \multirow{2}{*}{$\begin{array}{c}\text { BS } \\
\% \text { of CEC }\end{array}$} \\
\hline & \multicolumn{5}{|c|}{ Particle-size (\%) } & & & & & \\
\hline Native forest & 18.9 & 14.8 & 5.6 & 5.7 & 55 & 10.5 & 0.5 & 19.1 & 9.47 & 20.98 \\
\hline Beech & 20.6 & 15.8 & 5.9 & 7.0 & 50.6 & 6.5 & 0.4 & 17.7 & 8.0 & 18.63 \\
\hline Douglas-fir & 19.2 & 17.4 & 5.6 & 5.1 & 52.7 & 5.1 & 0.3 & 19.3 & 8.3 & 22.65 \\
\hline Spruce & 16.4 & 15.1 & 5.9 & 6.0 & 56.6 & 8.2 & 0.4 & 20.4 & 9.13 & 14.63 \\
\hline
\end{tabular}

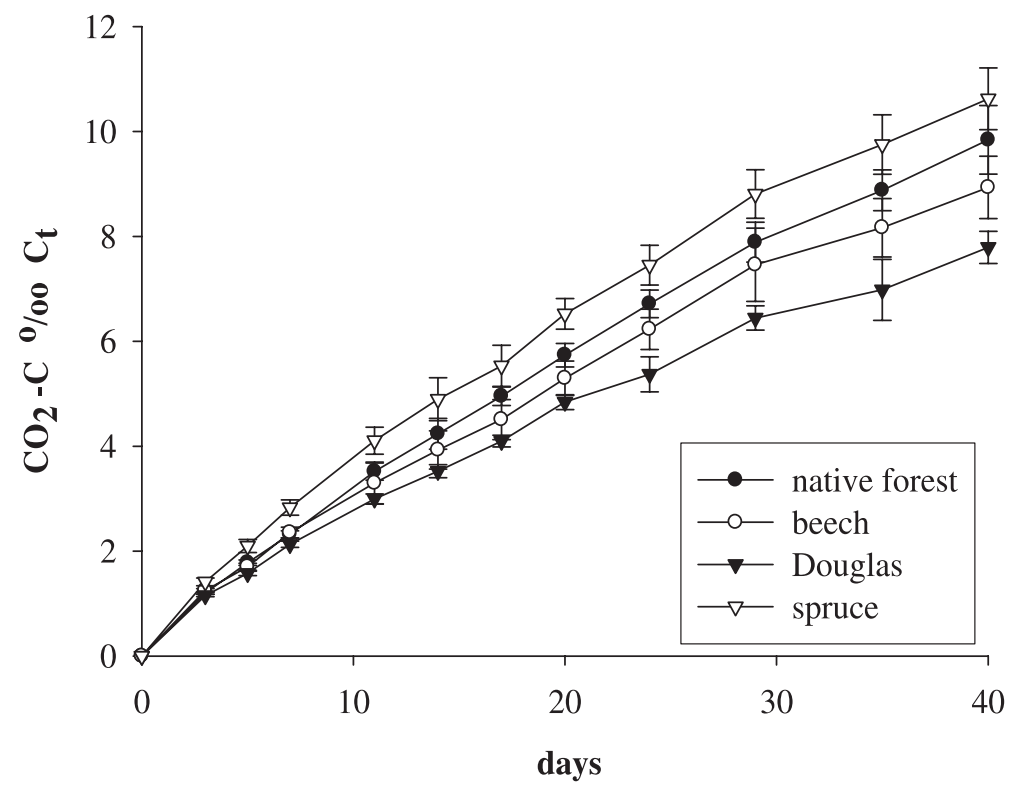

Figure 1. Cumulative amounts of $\mathrm{C}$-mineralized $\left(\mathrm{CO}_{2-}\right.$ $\mathrm{C} \%$ o. $\mathrm{C}_{t}$ ), during 40 days of soil sample incubation. Vertical bars represent standard deviation, $(n=25)$. Significant differences at $p<0.05$. contained more organic carbon $(10.5 \%)$ than those under 30 year-old plantations (Tab. I). The organic matter content decreased in the order: native forest $>$ spruce $>$ beech $>$ Douglas fir. The lowest $\mathrm{C} / \mathrm{N}$ ratio (17.7) was observed in beech soil, whereas it was close to 20 for the other species. Values for the base saturation index (BS) varied from $14.5 \%$ for spruce to $22.7 \%$ of CEC for Douglas-fir (Tab. I), all indicating that the soils were poorly saturated. Soils under native forest and spruce presented the highest CEC values and carbon content but the lowest clay contents. Soils under beech and Douglasfir plantations presented the lowest CEC values and carbon contents, but the highest clay content.

\subsection{Soil organic carbon mineralization}

For all the samples, the cumulated rates of carbon mineralized, expressed in proportion of total carbon as $\mathrm{CO}_{2}-$ $\mathrm{C} \%$ of $\mathrm{Ct}$, showed a linear kinetic during the incubation period (Fig. 1). The rate was always the highest for the spruce soil. After 40 days of incubation, the amount of carbon mineralized was of $10.6 \% 0,9.8 \%, 8.9 \%$ and $7.8 \%$, for Norway spruce, native forest, beech and Douglas-fir soil samples, respectively. Significant differences $(p<0.05)$ between soils were observed from the third day of incubation. The daily $\mathrm{C}$-mineralization rate for spruce reached $0.27 \%$ of the total soil organic carbon, whereas it varied between $0.25 \%$, $0.22 \% o$ and $0.19 \%$ for the native forest, beech and Douglas fir, respectively. By comparing the values of cumulative bulk production of $\mathrm{CO}_{2}-\mathrm{C}$ during 40 days, the soil under native forest showed the highest values $\left(1036 \mathrm{mg} \cdot \mathrm{kg}^{-1}\right)$ followed by Norway spruce $\left(869.3 \mathrm{mg} \cdot \mathrm{kg}^{-1}\right)$, beech $\left(581 \mathrm{mg} \cdot \mathrm{kg}^{-1}\right)$, and Douglas-fir (400.4 mg. $\mathrm{kg}^{-1}$ ).

\subsection{Nitrogen mineralization}

Total water-extractable mineral $\mathrm{N}$-contents $\left(\mathrm{NO}_{3}+\mathrm{NH}_{4}\right)$ $\mathrm{N}$ expressed in proportion of total nitrogen (Tab. II) were initially significantly the highest $(p<0.05)$ for soils under beech and Douglas-fir, and decreased in order: beech $\geq$ Douglas fir $>$ spruce $>$ native forest. After incubation, it increased significantly for all samples. It was always the lowest for the native forest soil $(6.7 \% 0)$ and the highest for beech soil (17.3\%o), $(p<0.05)$. Soil under spruce showed intermediate values between those under native forest and Douglas-fir Concerning the net $\mathrm{N}$-mineral production after 40 days of incubation, soil under beech released $7.32 \%$ of its total $\mathrm{N}$-content against $4.27 \%$, $4.59 \%$ and $3.35 \%$ for those under Douglasfir, spruce and native forest respectively.

Before incubation, the $\mathrm{NO}_{3}-\mathrm{N}$ content (Tab. II) was significantly higher for soils under Douglas-fir and beech than under spruce and native forest. It was the same after incubation $(p<0.05)$. The highest net nitrate production for the 40 days of incubation was observed for soil under beech $\left(22.8 \mathrm{mg} \cdot \mathrm{kg}^{-1}\right)$, whereas it was only of $16.2 \mathrm{mg} \cdot \mathrm{kg}^{-1}$, 
Table II. Water extractable nitrates, ammonium, total mineral nitrogen content in \%o of total N, Nitrification indices, WEOC content, and $\mathrm{pH}$, before $(0)$ and after $(40)$ days of incubation $(n=5)$. In parentheses are standard deviations. Significant differences $(p<0.05)$ according to Newman-Keuls-test are noted by different letters.

\begin{tabular}{lccccccc}
\hline Plots & $\begin{array}{c}\text { Periods } \\
(\text { day })\end{array}$ & $\begin{array}{c}\mathrm{NO}_{3}-\mathrm{N} \\
\left(\mathrm{mg} \cdot \mathrm{kg}^{-1} \text { dry soil }\right)\end{array}$ & $\begin{array}{c}\mathrm{NH}_{4}-\mathrm{N} \\
\left(\mathrm{mg} \cdot \mathrm{kg}^{-1} \text { dry soil }\right)\end{array}$ & $\begin{array}{c}\left(\mathrm{NO}_{3}+\mathrm{NH}_{4}\right)-\mathrm{N} \\
\left(\% \circ \mathrm{N}_{\mathrm{t}}\right)\end{array}$ & $\frac{\mathrm{NO}_{3}-\mathrm{N}}{\left(\mathrm{NO}_{3}+\mathrm{NH}_{4}\right)-\mathrm{N}}(\%)$ & $\begin{array}{c}\mathrm{WEOC} \\
\left(\% \circ \mathrm{C}_{\mathrm{t}}\right)\end{array}$ & $\begin{array}{l}\mathrm{WH} \\
(\mathrm{H} 2 \mathrm{O})\end{array}$ \\
\hline Native forest & 0 & $2.33^{\mathrm{f}}(0.05)$ & $16.39^{\mathrm{e}}(0.36)$ & $3.32^{\mathrm{g}}(0.11)$ & $12.48^{\mathrm{h}}(0.01)$ & $2.12^{\mathrm{d}}(0.05)$ & $3.82^{\mathrm{bc}}(0.01)$ \\
& 40 & $3.18^{\mathrm{f}}(0.18)$ & $33.51^{\mathrm{b}}(1.23)$ & $6.67^{\mathrm{f}}(0.23)$ & $8.67^{\mathrm{g}}(0.47)$ & $2.29^{\mathrm{cd}}(0.17)$ & $3.89^{\mathrm{b}}(0.11)$ \\
Beech & 0 & $13.19^{\mathrm{c}}(0.64)$ & $23.82^{\mathrm{d}}(0.41)$ & $10.01^{\mathrm{d}}(0.17)$ & $35.62^{\mathrm{d}}(1.33)$ & $2.61^{\mathrm{bc}}(0.16)$ & $3.86^{\mathrm{b}}(0.01)$ \\
& 40 & $35.96^{\mathrm{a}}(2.10)$ & $27.42^{\mathrm{c}}(1.84)$ & $17.33^{\mathrm{a}}(0.54)$ & $56.74^{\mathrm{c}}(1.57)$ & $2.41^{\mathrm{cd}}(0.26)$ & $4.04^{\mathrm{a}}(0.04)$ \\
Douglas & 0 & $19.57^{\mathrm{b}}(0.21)$ & $6.89^{\mathrm{f}}(0.38)$ & $9.80^{\mathrm{d}}(0.13)$ & $73.98^{\mathrm{b}}(1.16)$ & $3.67^{\mathrm{a}}(0.34)$ & $3.76^{\mathrm{cd}}(0.01)$ \\
& 40 & $35.74^{\mathrm{a}}(1.31)$ & $2.24^{\mathrm{g}}(0.52)$ & $14.07^{\mathrm{b}}(0.44)$ & $94.09^{\mathrm{a}}(1.40)$ & $2.68^{\mathrm{bc}}(0.31)$ & $3.89^{\mathrm{b}}(0.03)$ \\
Spruce & 0 & $5.80^{\mathrm{e}}(0.31)$ & $26.89^{\mathrm{c}}(0.46)$ & $8.17^{\mathrm{e}}(0.17)$ & $17.72^{\mathrm{f}}(0.65)$ & $2.93^{\mathrm{b}}(0.38)$ & $3.73^{\mathrm{d}}(0.00)$ \\
& 40 & $10.78^{\mathrm{d}}(0.35)$ & $40.27^{\mathrm{a}}(1.24)$ & $12.76^{\mathrm{c}}(0.32)$ & $21.11^{\mathrm{e}}(0.74)$ & $2.74^{\mathrm{bc}}(0.21)$ & $3.74^{\mathrm{d}}(0.05)$ \\
\hline
\end{tabular}

$5 \mathrm{mg} \cdot \mathrm{kg}^{-1}$ and $<1 \mathrm{mg} \cdot \mathrm{kg}^{-1}$ for Douglas-fir, spruce and native forest soils respectively.

Before incubation, the $\mathrm{NH}_{4}-\mathrm{N}$ content (Tab. II) decreased in the order: spruce $>$ beech $>$ native forest $>$ Douglas fir, but after incubation, the order became: spruce $>$ native forest $>$ beech $>$ Douglas fir, with a significant highest content of $40.3 \mathrm{mg} \cdot \mathrm{kg}^{-1}$ for spruce soil $(p<0.05)$. Concerning the net production of ammonium for the 40 days of incubation, soil from native forest released $17.1 \mathrm{mg} \cdot \mathrm{kg}^{-1}$ of NH4-N against $13.4 \mathrm{mg} \cdot \mathrm{kg}^{-1}$, and $3.6 \mathrm{mg} \cdot \mathrm{kg}^{-1}$ for soils under spruce and beech respectively. Oppositely, soil under Douglas-fir showed a decrease in its $\mathrm{NH}_{4}-\mathrm{N}$ content after incubation that corresponded to a loss of $4.65 \mathrm{mg} \cdot \mathrm{kg}^{-1}$ of ammonium.

Except for all the samples under the native forest, the nitrification index expressed by $\left[\mathrm{NO}_{3}-\mathrm{N} /\left(\mathrm{NO}_{3}+\mathrm{NH}_{4}\right)-\mathrm{N}\right] \%$, (Tab. II) increased during incubation. It was the highest, for the Douglas-fir soil, (94\% at the end of incubation), whereas it stayed around $20 \%$ and $10 \%$ respectively for the spruce and the native forest soils at all times.

\section{4. $\mathrm{pH}$ changes during soil organic matter biodegradation}

All soil samples were strongly acidic, as shown in Table II. The initial $\mathrm{pH}$ values varied from 3.8 to 4 and significantly increased $(p<0.05)$ during the incubation period for beech and Douglas fir soils.

\subsection{Water-extractable organic carbon (WEOC) and water-extractable elements (WE)}

Before incubation, the highest WEOC content (Tab. II) was observed in the soil from the Douglas fir plantation (3.7\%o of $\mathrm{C}_{t}$ ) and decreased in the following order Douglas-fir $>$ Norway spruce $>$ beech $>$ native forest $(p<0.05)$. After 40 days of incubation, organic matter biodegradation caused a decrease of WEOC content in all soil samples, except for the native forest, which slightly increased, but the differences were not significant. The WEOC content of the Douglas-fir and Norway spruce soil samples was similar, while the beech and native forest formed a second group of samples with similar WEOC content $(p<0.05)$. In addition, the Douglas fir soil samples showed the highest decrease of WEOC content corresponding to $1 \%$ of $\mathrm{C}_{t}$.

Water-extractable (WE) Ca (Fig. 2) was initially the highest for Douglas-fir soil and it decreased in the order: Douglas-fir $>$ native forest $>$ beech $>$ spruce. After incubation, Ca values increased for soils under Douglas-fir (from $17.5 \mathrm{mg} \cdot \mathrm{kg}^{-1}$ to $41 \mathrm{mg} \cdot \mathrm{kg}^{-1}$ ) and beech (from $5.5 \mathrm{mg} \cdot \mathrm{kg}^{-1}$ to $13.6 \mathrm{mg} \cdot \mathrm{kg}^{-1}$ ) $(p<0.05)$ whereas it decreased for those under native forest and spruce. Initial WE Mn (Fig. 2) was the highest for the Douglas-fir soil. After incubation, WE Mn values increased significantly for soils under Douglas-fir (from $3 \mathrm{mg} \cdot \mathrm{kg}^{-1}$ to $8 \mathrm{mg} \cdot \mathrm{kg}^{-1}$ ), and beech (from $0.6 \mathrm{mg} \cdot \mathrm{kg}^{-1}$ to $3.5 \mathrm{mg} \cdot \mathrm{kg}^{-1}$ ), $(p<0.05)$. For Norway spruce and native forest soils, WE Mn contents were the lowest at all time $\left(<0.4 \mathrm{mg} \cdot \mathrm{kg}^{-1}\right)$. Before incubation, WE Mg content (Fig. 2) was significantly higher for soil under Douglas-fir than for those under other species. After incubation, $\mathrm{Mg}$ content significantly increased $(p<0.05)$ for soils under Douglas-fir (from $4 \mathrm{mg} \cdot \mathrm{kg}^{-1}$ to $5.6 \mathrm{mg} \cdot \mathrm{kg}^{-1}$ ), beech (from $2.3 \mathrm{mg} \cdot \mathrm{kg}^{-1}$ to $3 \mathrm{mg} \cdot \mathrm{kg}^{-1}$ ), and spruce (from $2.6 \mathrm{mg} . \mathrm{kg}^{-1}$ to $3.3 \mathrm{mg} \cdot \mathrm{kg}^{-1}$ ). Oppositely, a decrease was observed for soil under native forest. WE Fe contents (Fig. 2) were initially the highest for native forest soil, and the lowest for Douglas-fir soil. After incubation, they decreased for all samples, except for the Norway spruce soil, where they increased (from $19.8 \mathrm{mg} \cdot \mathrm{kg}^{-1}$ to $28 \mathrm{mg} \cdot \mathrm{kg}^{-1}$ ). Before incubation, WE Al contents (Fig. 2) were initially the highest for soils under native forest and beech, and the lowest for Douglas-fir. Soil under Norway spruce occupied an intermediate position. After incubation WE Al content decreased for all soils except under Norway spruce where they significantly increased from $39.7 \mathrm{mg} \cdot \mathrm{kg}^{-1}$ to $54 \mathrm{mg} \cdot \mathrm{kg}^{-1}$.

\section{DISCUSSION}

In relation to the fine fraction and organic matter contents, it appears that soils with the highest CEC, and organic carbon contents presented the lowest clay contents (i.e. native forest and spruce) and inversely, that soils with the lowest $\mathrm{CEC}$, and organic carbon contents presented the highest clay 

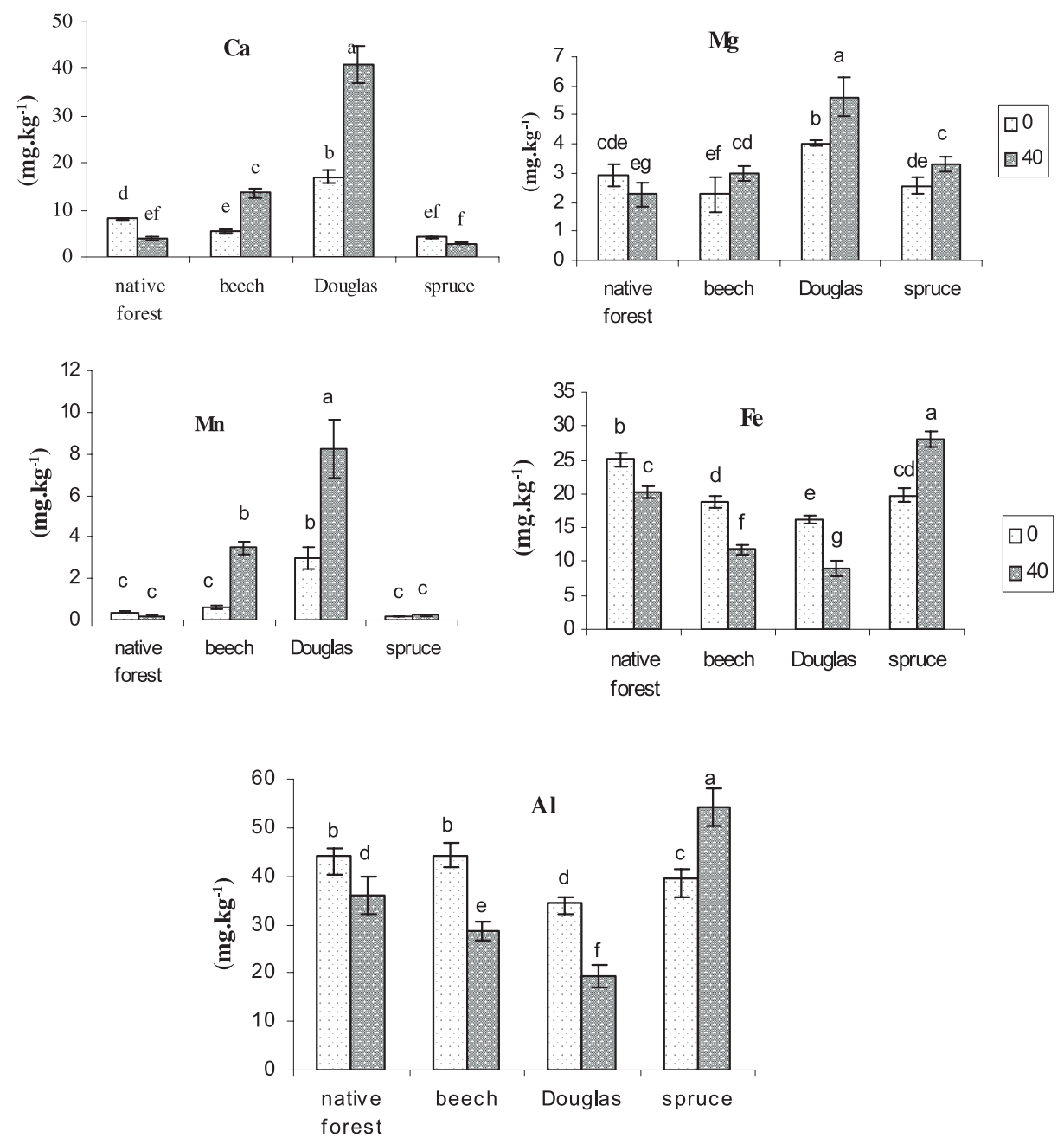

Figure 2. $\mathrm{Ca}, \mathrm{Mg}, \mathrm{Mn}, \mathrm{Fe}$ and $\mathrm{Al}$ waterextractable contents before $(0)$ and after (40) days of soil incubation, $(n=5)$. Significant differences $(p<0.05)$ according to Newman-Keuls test are marked by different letters.

contents (i.e. beech and Douglas-fir). This suggests that the exchangeable elements are mainly associated to organic matter, and not with the clay minerals. The incubation of the $\mathrm{A}_{1}$ $(0-5 \mathrm{~cm})$ layer originating from the same type of soil under different forest stands growing in similar local conditions showed different organic matter mineralization rates, in the following order: spruce $>$ native forest $>$ beech $>$ Douglas-fir $(p<0.05)$. This order is in agreement with the $\mathrm{C}: \mathrm{N}$ ratios, with the exception of an inversion between Norway spruce and native forest. In spite of their high organic matter content, the native forest soil samples did not show the highest C-mineralization. Such behaviour could be due to the higher biostability and recalcitrance of soil organic matter under the native forest, where organo-mineral complexes are older and less labile. In a chrono-sequence of ponderosa pine forest, Kelliher et al. [25] showed that the amount of extractable carbon was the highest for the young plot. In fact, in the present study, water-extractable organic matter was relatively higher in soils from beech plantations (30-year-old) than in the native forest. The elevated $\mathrm{C}$-mineralization rate observed for the Norway spruce soil suggests that efficient microbial communities were adapted or were specific for this plant material in the plot and/or that labile organic compounds were more avail- able despite acidic conditions [3, 16,41]. Taking into account the bulk production of $\mathrm{CO}_{2}-\mathrm{C}$ in $\mathrm{mg}$ per $\mathrm{kg}$ of soil, the native forest plot mineralized more carbon than the other plots, suggesting that both the quality and quantity of organic matter have to be considered as main parameters controlling organic matter biodegradability and mineralization.

The decrease of WEOC observed for all soil samples during incubation $(p<0.05)$, suggests that it can be degraded and mineralized by soil microorganisms [28]. Soils from coniferous plots (Douglas-fir and Norway spruce) were richer in water-extractable organic matter than those from deciduous plots (beech and native forest). Soil organic matter from the spruce appeared much more biodegradable than the Douglasfir ones which had the lowest organic matter content. As for $\mathrm{CO}_{2}-\mathrm{C}$ production, such observations could be related to the nature of the soil organic matter under each forest tree species, which appears again as a major parameter that need to be much better defined. For soils from a Douglas-fir site in Oregon (USA), Jandl and Sollins [20], showed that WEOC was essentially constituted by hydrophobic compounds recalcitrant to biodegradation. In addition, in all the treatments, the amount of WEOC was much lower than the amount of C-mineralised. This indicates that part of mineralized carbon was provided 
by non water-extractable organic matter or that there is a continuous production and release of soluble organic matter during biodegradation.

Soil samples from beech and Douglas-fir plantations were those having the highest release of net mineral nitrogen. Our results indicated that there was a major difference between soils under native forest and beech plantation. Native forest soil, which showed a relatively high organic carbon mineralization, presented a low net nitrogen mineralization with a low index of nitrification. The net $\mathrm{N}$-mineralization seemed to be hindered or limited at the ammonification stage. This suggests that with ageing forest tree species would strongly influence the litter quality and the microbial activities and consequently, the soil and whole ecosystem functions. Idol et al. [19], also observed a low nitrification under older plots in a 100-year hardwood chronosequence. Disturbances of topsoil caused by clear-cutting and plantation could also modify the soil properties and the microbial activity. As suggested by Paavolainen et al. [31], clear-cut significantly decreases the emission of compounds inhibiting nitrogen mineralization (i.e. 20000-fold less in clear-cut plot than in the forest).

Net nitrification was mainly the highest in soils originating from beech and Douglas-fir plantations. Beech soil appeared more efficient in nitrogen mineralization, but had a lower net nitrification than Douglas-fir soil. Nitrification was particularly active in Douglas-fir soil, as it has been observed in other sites, such as one studied in Beaujolais (France) [23], but also in beech litter $(p<0.05)$, as noted by Wedraogo et al. [47]. Both the native forest and spruce soils (richer in organic carbon than the beech and Douglas-fir plantations) presented the highest carbon mineralization rate and the lowest nitrification indices. This suggests that high soil organic matter content could limit nitrification as reported by Strauss and Lamberti [44], for stream sediments. Several hypotheses can be proposed to explain this divergence between carbon and nitrogen mineralization: allelopathy, microbial immobilisation and competition for nitrogen between micro-organisms. The allelopathy effect is attributed to chemical mediators, usually organic compounds like phenols, tannins and lignin, able to inhibit the activity of nitrifying bacteria [14, 26, 47]. Phenolic compounds leached from the litter itself could play an inhibiting role towards some microbial communities [3,22] Furthermore, Bruckert et al. [11] showed that soil microorganisms could also produce some antimicrobial compounds, like acetic and butyric acids that can limit some microbial activity in the soil. Other organic compounds, such as terpenoids, present in the litter and soil, are known to inhibit nitrification, particularly ammonium oxidation [13, 31, 36, 48]. However, terpene compounds do not have the same impact on $\mathrm{C}$-mineralization because they can be used as carbon source by microorganisms and can also contribute to $\mathrm{CO}_{2}$ production [31]. The immobilisation of mineral nitrogen by soil microorganisms, and particularly nitrates which are rapidly assimilated, was demonstrated by Stark and Hart [42]. Competition for $\mathrm{NH}_{4}-\mathrm{N}$ might also exist between heterotrophic bacteria and nitrifying bacteria, as proposed by Stoo et al. [43] and Strauss and Lamberti [44]. Such finding might explain why mineral nitrogen was mainly present as ammonium in the native forest and spruce soil samples.

The availability of water-extractable major elements varied with tree species. The high release of $\mathrm{Ca}, \mathrm{Mn}$ and $\mathrm{Mg}$, during the organic matter biodegradation under Douglas-fir and beech, can be related to the higher release of nitrate which affects efficiently $\mathrm{Ca}$ and $\mathrm{Mg}$ solubilization through the proton budget [47]. This was confirmed by the high significant correlation observed after incubation between $\mathrm{NO}_{3}-\mathrm{N}$ and: $\mathrm{Mn}$ $(r=0.898, p<0.00001), \mathrm{Ca}(r=0.77, p<0.00001)$, and $\mathrm{Mg}(r=0.70, p<0.00058)$. The efficiency of nitrification in weathering processes and $\mathrm{Ca}, \mathrm{Mg}$ solubilization has been recognized in some brown acid soils on granitic rocks [4]. The increase of $\mathrm{pH}$ observed after incubation can be due to the release of $\mathrm{Mn}$ and $\mathrm{Ca}$ which were significantly correlated with $\mathrm{pH}(r=0.5044, p<0.0233$ for $\mathrm{Mn})$, and $(r=0.4625$, $p<0.040$ for $\mathrm{Ca}$ ). The strong release of $\mathrm{Al}$ and $\mathrm{Fe}$ observed after incubation of soil under spruce could be attributed to the production and/or biodegradation of organo-metallic complexes [14]. Indeed as reporteded by Duchaufour [14], and McKeague et al. [29], under coniferous plots, low-molecular weight organic acids such as citric and oxalic acids might be involved in complexing $\mathrm{Al}$ and $\mathrm{Fe}$ before their use as carbon and energy sources by the microorganisms.

The PCA allowed to clearly separate the tree species effect, based on soil properties, $\mathrm{C}$ and $\mathrm{N}$ mineralization behaviour and fate of nutriments during incubation time. Figures 3 and 4 illustrated the results obtained respectively before and after soil incubation. In Figure 3, the horizontal F1 and vertical F2 axis respectively explained $60 \%$ and $19 \%$ of total variance. The F1 axis was determined on one hand, by the nitrate and waterextractable $\mathrm{Ca}, \mathrm{Mg}$, and $\mathrm{Mn}$ contents, and on the other hand, by the water-extractable $\mathrm{Fe}$ and $\mathrm{Al}$ contents. This axis tended to oppose the soil under Douglas-fir to those under native forest, spruce and beech plantations. The F2 axis was determined by WEOC and $\mathrm{NH}_{4}-\mathrm{N}$ on one hand, and by $\mathrm{pH}, \mathrm{Ca}$ and $\mathrm{Fe}$, on the other hand. It opposed soils under spruce and native forest; those under beech and Douglas fir occupied an intermediate position. At the end of the incubation (Fig. 4), the tendencies observed on the initial set data were confirmed and emphasised. The F1 axis explained $66 \%$ of the total variance and opposed the soils under Douglas-fir and beech to those under spruce and native forest. The F2 axis explaining $20 \%$ of the total variance was determined by $\mathrm{pH}$ and WEOC values. It opposed soils under deciduous and coniferous species. Soils under beech and native forest seem to be opposed more on the basis of nitrate and solubilized mineral elements (i.e. nutrients and/or $\mathrm{Al}+\mathrm{Fe}$ ) than on their $\mathrm{pH}$. The same applies for the opposition between soils under spruce and Douglas-fir. This also means that the impact of "acidifying tree species" was noticeable only on the soil under spruce, not on that under native forest. In fact, the F2 axis clearly reflects the lower $\mathrm{pH}$ values and higher WEOC contents of soils under coniferous trees, as also shown in Figures 3 and 4.

This indicates that the tree species are major parameters affecting the dynamics and activity of microbial communities and the dynamics and availability of nutrients in soil. But, the age of the trees and the land use (clear-cut) as shown by Jussy 

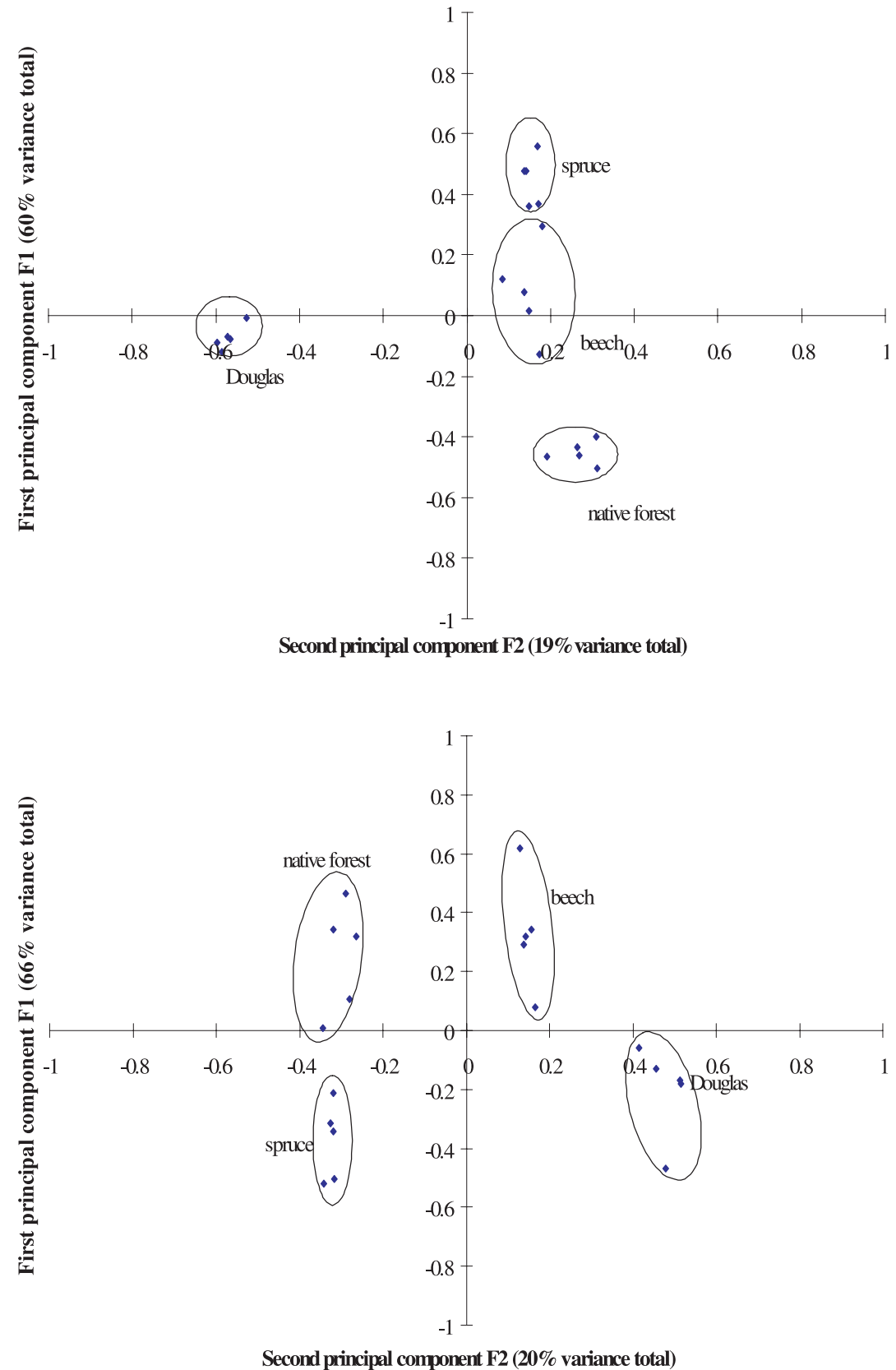

Figure 3. PCA of soil samples data obtained before incubation (time 0). Variables were: WEOC, $\mathrm{NO}_{3}$ $\mathrm{N}, \mathrm{NH}_{4}-\mathrm{N}, \mathrm{Ca}, \mathrm{Mg}, \mathrm{Mn}, \mathrm{Al}, \mathrm{Fe}$ contents and $\mathrm{pH}$. $(n=20)$.
Figure 4. PCA of soil samples data obtained after incubation (40 days). Variables were: $\mathrm{WEOC}, \mathrm{NO}_{3}-$ $\mathrm{N}, \mathrm{NH}_{4}-\mathrm{N}, \mathrm{Ca}, \mathrm{Mg}, \mathrm{Mn}, \mathrm{Al}, \mathrm{Fe}$ contents and $\mathrm{pH}$. $(n=20)$. et al. [24] and Bonneau [9], may also be involved in these dynamics.

\section{CONCLUSION}

Soil incubations for 40 days, under laboratory conditions, allowed to observe an effect of tree species on organic matter biodegradability and consequently on mineral element and major nutriments release and availability. The results showed that carbon mineralization and nitrogen mineralization can be divergent. Major differences in mineral elements solubilization are also observed between tree species. But, to evaluate more accurately the impact of tree species, further studies are needed in a long-term incubation so as to determine the extent and dynamic of the biodegradation of organic matter, the nature of water extractable organic compounds, their role in mineral availability, and/or as antimicrobial agent controlling dynamic and activity of bacterial and/or fungal communities such as the nitrifying bacteria.

Acknowledgements: This study was financed by GIP Ecofor (biodiversity program). We are grateful to D. Gelhaye, P. Bonnaud, G. Belgy and D. Merlet for assistance in field and in the lab. We also thank D. Fortin and B. Zeller for their advice and suggestions on the manuscript. 


\section{REFERENCES}

[1] Augusto L., Ranger J., Binkley D., Rothe A., Impact of several common tree species of European temperate forest on soil fertility, Ann. For. Sci. 59 (2002) 233-253.

[2] Aurousseau P., Morphologie et genèse des sols sur granite du Morvan, Thèse de Docteur-Ingénieur, Université de Rennes, 1976.

[3] Beck G., Dommergues Y., Van Den Driessche R., L'effet litière. Étude expérimentale du pouvoir inhibiteur des composés hydrosolubles des feuilles et des litières forestières vis-à-vis de la microflore tellurique, Ecol. Plant. 4 (1969) 237-266.

[4] Berthelin J., Bonne M., Belgy G., Wedraogo F.X., A major role for nitrification in weathering of minerals of brown acid forest acid soils, Geomicrobiol. J. 4 (1984) 175-190.

[5] Berthelin J., Leyval C., Toutain F., Biologie des sols, rôle des microorganismes dans l'altération et l'humification, in: Bonneau M. Souchier B. (Eds.), Pédologie, tome 2, Constituants et propriétés du sol, Masson, Paris, 1994, pp. 143-237.

[6] Berthelin J., Munier-Lamy C., Portal J.M., Physico-chemical characterization reactivity and biodegradability of soil natural organic matter, in: Baveye P., Block J.-C., Goncharuk V. (Eds.), Bioavailability of organic xenobiotics in the environment, Kluwer Academic Publishers, Netherlands, 1999, pp. 251-296.

[7] Binkley D., The influence of tree species on forest soils processes and patterns, in: Mead D.J., Cornforth I.S. (Eds.), Proceedings of the Tree and soil Workshop, Agronomy Society of New Zealand, Canterbury, 1995, pp. 1-33.

[8] Binkley D., Giardina C., Why do tree species affect soils? The warp and woop of tree - soil-interaction, Biogeochemistry 42 (1998) 89106.

[9] Bonneau M., Evolution of the mineral fertility of an acidic soil during a period of ten years in the Vosges mountains (France). Impact of humus mineralisation, Ann. For. Sci. 62 (2005) 253-260.

[10] Bonneau M., Brethes A., Lacaze J.F., Letacon F., Levy G., Nys C., Modification de la fertilité des sols sous boisement artificiel de résineux purs, Institut National de la Rrecherche Agronomique, DGRST, Nancy Champenoux, 1977.

[11] Bruckert S., Dommergues Y., Weinhard P., Boymond D., Effet litière : influence de l'anaérobiose sur la production des composés antimicrobiens hydrosolubles, Ecol. Plant 5 (1970) 137-146.

[12] Cote L., Brown S., Pare D., Fyles J., Bauhus J., Dynamics of carbon and nitrogen mineralization in relation to stand type, stand age and soil texture in the boreal mixed wood, Soil Biol. Biochem. 32 (2000) 1079-1090.

[13] Deluca T.H., Nilson M.C., Zackarisson O., Nitrogen mineralization and phenol accumulation along a fire chronosequence in Northern Sweden, Ecologia 133 (2002) 206-214.

[14] Duchaufour P., Introduction à la science du sol. Sol-VégétationEnvironnement, Dunod, Paris, 2001.

[15] Fisher R., Binkley D., Ecology and management of forest soils, John Wiley and Sons, Inc., New York, 2000.

[16] Gallet C., Lebreton P., Profils phytochimiques au sein d'une pessière d'altitude, Acta Biol. Mont. 9 (1989) 143-152.

[17] Giardina C.P., Ray M.G., Hubbard R.M., Binkley D., Tree species and soil texture controls on carbon and nitrogen mineralization rates, Soil Sci. Am. J. 65 (2001) 1272-1279.

[18] Hurlbert S.H., Pseudoreplication and the design of ecological field experiments, Ecol. Monogr. 54 (1984) 187-211.

[19] Idol T.W., Pop P.E., Ponder F.J., N-mineralization, nitrification and $\mathrm{N}$-uptake across a 100-years chronosequence of upland hardwood forests, For. Ecol. Manage. 176 (2003) 509-519.
[20] Jandl R., Sollins P., Water-extractable soil carbon in relation to the belowground carbon cycle, Biol. Fertil. Soils 25 (1997) 196-201.

[21] Jenkinson D.S., The fate of plant and animal residues in soil, in: Greenland D., Hayes M. (Eds.), The chemistry of soil processes, John Wiley and Sons, Ltd., New York, 1981, pp. 505-561.

[22] Jung G., Bruckert S., Dommergues Y., Étude comparée de diverses substances hydrosolubles extraites de quelques litières tropicales et tempérées, CEcol. Plant. 3 (1969) 237-253.

[23] Jussy J.H., Colin-Belgrand M., Ranger J., Production and root uptake of mineral nitrogen in a chronosequence of Douglasfir (Pseudotsuga menziesii) in the Beaujolais Mounts, For. Ecol. Manage. 128 (2000) 197-209.

[24] Jussy J.H., Ranger J., Bienaimé S., Dambrine E., Effects of a clearcut on the in situ nitrogen mineralization and the nitrogen cycle in a 67-year-old Douglas-fir (Pseudotsuga menziesii (Mirb.) Franco) plantation, Ann. For. Sci. 61 (2004) 397-408.

[25] Kelliher F.M., Ross D.J., Law B.E., Baldocchi D.D., Rodda N.J., Limitations to carbon mineralization in litter and mineral soil of young and old ponderosa pine forests, For. Ecol. Manage. 191 (2004) 201-213.

[26] Kraus T.E.C., Dahlgren R.A., Zasosk R.J., Tannins in nutrient dynamics of forest ecosystems, a review, Plant Soil 256 (2003) 41-66.

[27] Mangenot F., Toutain F., Les litières, in: Pesson P. (Ed.), Actualités d'écologie forestière : Sol-Flore-Faune, Gauthier-Villars, Paris, 1980 , pp. 3-59.

[28] Marschner B., Bredow A., Temperature effects on realise and ecologically relevant properties of dissolved organic carbon in sterilised and biologically active soil samples, Soil Biol. Biochem. 34 (2002) 459-466.

[29] Mckeague J.A., Cheshire M.V., Andreux F., Berthelin J., OrganoMineral complexes in relation to pedogenesis, in: Soil Science Society of America (Ed.), Interaction of Soil Mineral with natural Organics and Microbes, Madison, USA, 1986, pp. 549-592.

[30] Mohr D., Topp W., Hazel improves soil quality of sloping oak stands in a German low mountain range, Ann. For. Sci. 62 (2005) $23-29$.

[31] Paavolainen L., Kitunen V., Smolander A., Inhibition of nitrification in soil by monoterpenes, Plant Soil 205 (1998) 147-154.

[32] Pinto P.E., Gégout J.-C., Assessing the nutritional and climatic response of temperate tree species in the Vosges Mountains, Ann. For. Sci. 62 (2005) 761-770.

[33] Ponge J.-F., Humus forms in terrestrial ecosystems: a framework to biodiversity, Soil Biol. Biochem. 35 (2003) 935-945.

[34] Ranger J., Andreux F., Bienaimé S., Berthelin J., Bonnaud P., Boudot J.P., Bréchet C., Buée M., Calmet J.P., Chaussod R., Gelhaye D., Gelhaye L., Gérard F., Jaffrain J., Lejon D., Le Tacon F., Lévêque J., Maurice J.P., Merlet D., Moukoumi J., Munier-Lamy C., Nourrisson G., Pollier B., Ranjard L., Simonsson M., Turpault M.P., Vairelles D., Zeller B., Effet des substitutions d'essence sur le fonctionnement organo-minéral de l'écosystème forestier, sur les communautés microbiennes et sur la diversité des communautés fongiques mycorhiziennes et saprophytes (cas du dispositif expérimental de Breuil - Morvan), Rapport final du contrat INRA-GIP Ecofor 2001-24, Nancy N ${ }^{\circ} 1502 \mathrm{~A}, 2004$.

[35] Ranger J., Nys C., Effect of spruce plantation (Picea abies. Karst.) on the soil function of a previous broadleaved ecosystem: Analytical and experimental investigations, in: Teller A., Mthy P., Jeffers J. (Eds.), Responses of forest ecosystems to environmental changes, Elsevier, London, 1992, pp. 784-785.

[36] Rodgers G.A., Potency of nitrification inhibitors following their repeated applications to soil, Biol. Fertil. Soils 2 (1986) 105-108. 
[37] Rouiller J., Souchier B., Bruckert S., Feller C., Toutain F., Védy J.C., Méthodes d'analyses des sols, in : Bonneau M., Souchier B. (Eds.), Pédologie, tome 2: Constituants et propriétés du sol, Masson, Paris, 1994, pp. 619-652.

[38] Rovira P., Vallejo V.R., Labile and recalcitrant pools of carbon and nitrogen in organic matter decomposing at different depths in soil An acid hydrolysis approach, Geoderma 107 (2002) 109-141.

[39] Seddoh F., Altération des roches cristallines du Morvan (granites, granophyres, rhyolithes) : études minéralogiques, géochimiques et micromorphologiques, Thèse de Doctorat, Université de Dijon, 1973.

[40] Simonsson M., Kaiser K., Danielsson R., Andreux F., Ranger J., Estimating nitrate, dissolved organic carbon and DOC fractions in forest floor leachates using ultraviolet absorbance spectra and multivariate analysis, Geoderma 124 (2005) 157-168.

[41] Smolander A., Kitunen V., Soil microbial activities and characteristics of dissolved organic carbon and nitrogen in relation to soil tree species, Soil Biol. Biochem. 34 (2002) 651-660.

[42] Stark J.M., Hart S.C., High rates of nitrification and nitrate turnover in undisturbed coniferous forests, Nature 385 (1997) 61-64.
[43] Stoo H.F., Klein T.M., Alexander M., Heterotrophic nitrification in an acid forest soil and by an acid tolerant fungus, Appl. Environ. Microbiol. 52 (1986) 1107-1111.

[44] Strauss E.A., Lamberti G.A., Effect of dissolved organic carbon quality on microbial decomposition and nitrification rate in stream sediments, Freshwater Biol. 47 (2002) 65-74.

[45] Toutain F., Activité biologique des sols, modalités et lithodépendance, Biol. Fertil. Soils (1987) 31-39.

[46] Weber J.H., Binding and transport of metals by humic materials, in: Frimmel F.H., Christman R.F. (Eds.), Humic substances and their role in the environment, Report of the Dahlem Workshop, Life Science Research 41, Wiley, John and Sons, Chichester, 1988, pp. $165-178$.

[47] Wedraogo F.X., Belgy G., Berthelin J., Seasonal nitrification measurements with different species of forest litters applied to granite sand filled lysimeters in the field, Biol. Fertil. Soils 15 (1993) $28-34$.

[48] White C., Volatile and water-soluble inhibitors of nitrogen mineralization and nitrification in a ponderosa pine ecosystem, Biol. Fertil. Soils 2 (1986) 97-104. 